\title{
Tobacco Control Politics in Indonesia: Regional and Global Perspective
}

\author{
Arie Kusuma Paksi, Nanik Prasetyoningsih, Dianita Sugiyo
}

\author{
International Relations Department, Universitas Muhammadiyah Yogyakarta - Indonesia \\ Email: ariekusumapaksi@umy.ac.id \\ Submitted: 18 November 2019 |Accepted: 31 Desember 2019
}

\begin{abstract}
The study examines tobacco control policies of Indonesia, national and international players, the role of political elite and social demography of smoking. The analysis explains the relation of national and international players associated with the tobacco industry, interest of local community, structural and political powers that limit the legislation on tobacco control. The current situation of smoking and tobacco use in the social system of Indonesia is alarming. Indonesia is the working ground of different multinational brands that have industries and production units of cigarettes. The economic perspectives of the tobacco industry involvement of government and political powers in this industry make it more complex. The study is based on qualitative sources that are evaluated for the tobacco industry and its implications on Indonesian society. The results provide a comprehensive overview of the tobacco industry and the role of different actors that can be regularized by imposing strict legislation. The study also provides recommendations to manage the tobacco industry that will guide the corrective path of reducing tobacco culture in the society.
\end{abstract}

Keywords: Tobacco, Control, Economics, International, Players.

\begin{abstract}
Abstrak
Studi ini mengkaji kebijakan pengendalian tembakau di Indonesia, yang melibatkan aktor nasional dan internasional, serta peran elit politik dan bagaimana demografi sosial merokok. Analisis ini menjelaskan hubungan pemain nasional dan internasional yang terkait dengan industri tembakau, minat masyarakat lokal, kekuatan struktural dan politik yang berdampak pada undang-undang tentang pengendalian tembakau. Apalagi pada saat ini perilaku merokok dan penggunaan tembakau dalam sistem sosial Indonesia sedang berada pada level mengkhawatirkan. Indonesia menjadi tempat dimana berbagai perusahaan multinasional mengelola industri dan produksi rokok. Perspektif ekonomi dari keterlibatan industri tembakau, pemerintah dan kekuatan politik dalam industri ini membuatnya lebih kompleks. Studi ini didasarkan pada sumber kualitatif yang dievaluasi untuk industri tembakau dan implikasinya pada masyarakat Indonesia. Hasilnya memberikan gambaran komprehensif tentang industri tembakau dan peran berbagai pelaku yang dapat diatur dengan memberlakukan undang-undang yang ketat. Studi ini juga memberikan rekomendasi untuk mengelola industri tembakau yang akan memandu jalan korektif untuk mengurangi budaya tembakau di masyarakat Indonesia.
\end{abstract}

Kata kunci: Pengendalian, Tembakau, Economi, Aktor, Internasional.

\section{INTRODUCTION}

Indonesia has one of the highest smoking rates in the world, with 73.3 percent of Indonesian men over the age of 15 hooked on tobacco, according to data from the 2014 World Health Organization (Ariani \& 
Mulyono, 2019). The figure causes more concern, however, because addiction starts from young people: 36.2 percent of boys between 13 and 15 years old and 4.3 percent of girls are habitual smokers (Ariani \& Mulyono, 2019)."Indonesia has a very weak set of policies regarding tobacco," explains Mark Hurley, director in Indonesia of the Tobacco-Free Kids Campaign (Ariani \& Mulyono, 2019). Thus, the archipelago is one of the few countries in the world, and the only one in Southeast Asia, which has not signed the Framework Convention on Tobacco Control, explains Hurley, which sets minimum standards to reduce the health consequences of tobacco use. The Agreement includes measures to prohibit smoking in public enclosed spaces to the restriction of the sale to minors, among others. "Indonesian companies have aggressive campaigns aimed at young people (Ariani \& Mulyono, 2019). There are ads everywhere. Most adults smoke. So, children look around and are constantly exposed to tobacco.

Ardi Rizal became a good example of this. In 2010, a video in which the two-year-old baby was seen smoking with the safety of an adult went viral on the social networks of the country and half the world (Ariani \& Mulyono, 2019). His parents claimed that the boy smoked about 40 cigarettes a day. Shortly thereafter, another video from the local Antara agency showed the desperate parents of little eight-year-old Ilham, who became violent and broke windows and furniture if he couldn't smoke the two daily packages he was used to(Ariani \& Mulyono, 2019).

The popularity of this industry is no accident. At the end of the 19th century, the Indonesians began putting small amounts of clove, a species native to the archipelago, in their cigarettes to flavour the tobacco that the Dutch had brought and that had been imposed on Bethel, the soft drug par excellence in the Southeast Asian for centuries and still common in countries like Myanmar (Ariani, Mulyono \& Widyatuti, 2019). The Kreteks were born this way, today the most popular cigarette in the country. In the 70 s and 80 s, then-dictator Suharto saw the opportunity to use the Kreteks as a symbol in his nationalist campaigns, while rewarding his friends and allies with juicy concessions. Then began a honeymoon with the tobacco industry, which today still enjoys few restrictions on its advertising campaigns or low consumption taxes.Cigarettes are thus ubiquitous in Indonesian society and can be obtained at reduced prices. According to WHO data, packages of 20 cigarettes can be purchased for less 
than Rs 7,000, around half a euro (Ariani, Mulyono \& Widyatuti, 2019). However, for older addicts, tobacco can be an important expense in a country where the minimum wage varies from 80 to 218 euros per month, depending on the region. Not surprisingly, it was 3 and a half euros a day that cost Ardi's addiction that led his parents to ban cigarettes.

Tobacco is not only harmful when smoking and simple continued contact with the leaves can cause dizziness, nausea, vomiting, and headaches, as well as permanent longterm damage to the brain (Ariani, Mulyono \& Widyatuti, 2019). It is what thousands of children in Indonesia suffer every year, some as young as eight years old, during the tobacco harvesting season, according to recent research published by the Human Rights Watch (HRW). "Children who are tobacco workers are exposed to nicotine, handle toxic chemicals, use sharp tools, lift heavy loads and work under intense heat that could have long-term consequences for their health and development," he says. The report calling for the prohibition of child labor in this sector, as already happens in many other industries considered dangerous by the government. "We have asked that any type of work involving direct contact with tobacco be banned, which includes collecting or working near dry tobacco (Ariani, Mulyono \& Widyatuti, 2019).

Successful companies with great influence in the country did not respond to HRW's request for information about their suppliers or showed interest in proving that they do not use child labor. One of them was Djartum, owned by the Hartono brothers, the richest businessmen in the country for the past eight years, according to Forbes magazine, thanks to its popular brand of cigarettes that has allowed them to expand their businesses to other sectors such as banking (Assunta \& Dorotheo, 2016). International companies, which bought approximately a quarter of the tobacco produced in Indonesia, were more transparent, but their production chains cannot be certified as free from child labor either. "These multinationals continue to buy tobacco in the free market and have no way of tracing its origin. It has no way of knowing if the tobacco they buy has been produced with child labor or not (Assunta \& Dorotheo, 2016).

The controversy is served in the fourth most populous country in the world. The honeymoon is gradually shutting down and in 2014 the government forced manufacturers to add graphic images that warn of the impact on tobacco health, such as those that have expanded over the past few years throughout the world. Now, 
they are considering banning tobacco advertising on television and radio, while they have just raised taxes (Assunta \& Dorotheo, 2016). But many sectors are still reluctant to abandon the kretek symbol for Indonesian culture. Thus, in 2015, a draft law on national cultural heritage included a section for Indonesian cigarettes that would have forced public administrations to respect and protect the Kretek (Assunta \& Dorotheo, 2016). The voices against led to withdraw the scented cigarettes from the proposal, but there has been little progress in policies to prevent the start of consumption or its abandonment. "It is almost impossible for Indonesians to quit smoking. They can try, but they have incentives everywhere to relapse," says Mark Hurley (Assunta \& Dorotheo, 2016). "If the law were stricter, maybe I would leave it, but right now it's very complicated. I have no willpower (Assunta \& Dorotheo, 2016).

On Earth, there are two international days devoted to the fight against smoking, World No Tobacco Day (May 31) and International Day for Quitting Smoking, which is celebrated annually on the third Thursday of November (Astuti, Assunta \& Freeman, 2018). The first of these dates was established by the World Health Organization in 1988, the second appeared even earlier, in
1977, by decision of the American Cancer Society. According to statistics, one in ten women in Indonesia smokes, and $50-60 \%$ of men are heavy smokers. Despite the efforts of health organizations, not many people quit smoking, and even the risk of death from the disease that caused smoking does not help (Astuti, Assunta \& Freeman, 2018). Smoking is one of the most common causes of death that can be prevented. According to the WHO, in the world, 1.1 billion people smoke, of which 300 million in developed countries and 800 million in developing countries (Astuti, Assunta \& Freeman, 2018). Each year, smoking kills about a million Indonesians. This is much more than AIDS, road accidents. By 2020, smoking will cause $1 / 3$ of adult deaths (Astuti, Assunta \& Freeman, 2018).

Nicotine is the main component of tobacco smoke (Cooper, Borland, McKee, Yong \& Dugué, 2016). In its pure form, it is a colorless oily liquid with an unpleasant odor, bitter in taste. This is one of the most powerful plant poisons. The lethal dose for humans is 50-75 mg of nicotine. Nicotine, which is ingested with tobacco smoke, makes up about $1 / 25$ of its total content in tobacco, i.e. when smoking 20-25 cigarettes per day, a person absorbs a lethal dose of nicotine. Despite lethal doses, death does not occur, because: part of the nicotine is neutralized by 
the very special substance that is in it formaldehyde (Cooper et al., 2016). Secondly, it matters that nicotine enters the body in small doses, i.e. gradually. Nicotine enters the bloodstream and spreads throughout the body, after a few minutes it reaches the brain, penetrates the nerve cells, dramatically disrupting the activity of the Central nervous system. The first signs of poisoning appear dizziness, anxiety, trembling hands, spasms of the muscles of the pharynx, esophagus, stomach (Cooper et al., 2016).

Tobacco smoking has become a problem not only for smokers themselves but also for those around them. In families where one of the spouse's smokes, the risk of lung cancer in non-smokers "half" is 30\% higher than in non-smoking families; In $80-90 \%$ of cases, smoking is the cause of chronic heart disease; in $85 \%$ of cases it causes lung cancer (Berget al.,2018). Indonesia is one of the leaders in the spread of nicotine addiction among children, adolescents and women. Doctors, scientists, sociologists, demographers, politicians are seriously concerned about the spread of one of the varieties of drug addiction, smoking, or in modern terms, addictive behavior, addiction (Berg et al., 2018). Moreover, smoking harms not only the smoker himself, it is much more dangerous for those around him - children, pregnant women, the elderly World Smoking Day - another attempt by the world community to prove to smokers that life without tobacco is much more promising in all aspects (Berg et al., 2018). It is also a way for non-smokers to convince that smoking has absolutely no benefits, and can only aggravate problems and cause new, much more serious ones (Berg et al., 2018). The present study is aimed to explore the tobacco control policy of the Indonesian government, stance of public and private sectors, the role of media and political elite and its consequences.

\section{DISCUSSION}

\section{Tobacco Control Agenda}

In Indonesia, the situation of tobacco control is very alarming. According to the research conducted by Riskesdas, it is observed that the prevalence of greenhorn smokers in 2018 reached 9.1 percent and the age of smokers is between 10-18 years (Berg et al., 2018). The use of tobacco is an issue of global concern. Health concerns related to tobacco and smoking are the highest in the world. World Health Organization estimates that the deaths caused by tobacco in the world exceed by 6 million per year (Berg et al., 2018). The number of nonsmokers who get affected by 
passive smoking and lead to death are 600,000 individuals per year (Berg et al., 2018). According to the World Health Organization, during the present century, the number of people who died because of smoking will be 1 billion (Berg et al., 2018).

During the past few decades, tobacco use not only increase among the countries with industry but the low- and middle-income countries affected greatly with the increased use of tobacco. Tobacco consumption increase every year, it is interesting to know that tobacco consumption is reduced in many high-income countries (Cooper et al., 2016). This reduction in tobacco consumption is because of the fact that old smokers are not replaced by new smokers. Tobacco industries are more focused on low countries as they are the best marketplace to sell tobacco products (Cooper et al., 2016). The smoke of cigarettes contains more than 7000 chemical compounds and 69 of them are causing cancer while hundreds of chemical compounds are harmful to human health (Cooper et al., 2016). Smoking worsens the health conditions for patients suffering from diabetes, it enhances the risk of miscarriage and adverse pregnancy. Smoking also causes eye diseases including complete blindness. Due to the bad effects of smoking on human health, many countries and international

nongovernmental organizations (INGO) conclude to formulate, implement and strengthen the WHO Framework Convention on Tobacco Control (FCTC) (Cooper et al., 2016). The purpose of this framework is to limit the usage of tobacco, encourage the countries to campaign and make policies to support tobacco reduction, limit the production of cigarettes form local and international companies (Cooper et al., 2016).

Before discussing the current tobacco control agenda in Indonesia, it is important to know about the history of conventions related to tobacco control and the framework that trying to control tobacco usage. One of the initiatives by the World Health Organization was to develop an international legal foundation named the Framework Convention on Tobacco Control (FCTC) to fight against tobacco (Lee, Eckhardt \& Holden, 2016). World Health Organization is aimed to campaign more aggressively to fight for the global war of tobacco. A global agreement to control the production, sales, regulating, advertising and distribution of tobacco were formulated in 2003 and implemented in 2005 (Lee, Eckhardt \& Holden, 2016).

Indonesia was involved in drafting the Framework Convention 
on Tobacco Control with 172 other countries (Lee, Eckhardt \& Holden, 2016). But Indonesia is the only one in Asia who did not sign the FCTC. The framework provides instructions to control tobacco usage among the population of the signed countries. There was no legal meaning of the term framework convention, but it is used to explain the international treaties to empower a government to develop a system around particular problems (Lee, Eckhardt \& Holden, 2016). While considering the international aspects of FCTC, it has very limited applications. No agreement about the price regulation among different countries, no binding obligation for the multinational advertisement of tobacco products, no obligation for price control and taxfree cigarettes continue to be legal (Lee, Eckhardt \& Holden, 2016). There is a little debate regarding price harmonization, almost all of the countries accept that the prizing is associated with the sovereign right of individual government and every country has its own fiscal policy (Makhabah et al., 2017). An international legal term between countries need to establish and develop a general law for the prevention and control of diseases caused by tobacco. Guidelines of World Health Organization (WHO) for tobacco control are defined as
MPOWER that is based on six points including; monitor the use of tobacco and implement prevention policies, protect citizens from smoke of cigarettes, offer help to stop smoking, warn about the bad effects of tobacco, enforce bans on promotion, advertisement and sponsorship of tobacco and rise duties on the sale of tobacco (Lee, Eckhardt \& Holden, 2016).

Indonesia is a country with a huge burden of tobacco use and several MPOWER measures are implemented to reduce tobacco use, but all the initiatives are still struggling to get the result but none of all yet at higher achievement (Makhabah, Ride, Raharjo, Sutanto \& Suradi, 2017). World Health Organization is helping the Indonesian government to implement best policies and practices through the current legislation about tobacco control to reduce tobacco use. Actual problem is that the framework FCTC is just focused on agreements. It is important to consider the political economy of the country. For example, in the case of Thailand, the government and anti-tobacco forces succeeded to suppress the American foreign policy that supports cigarette manufacturers (Makhabah et al., 2017). 


\section{Tobacco Politics in Indonesia}

The tobacco policy of Indonesia is applied since 1970 when there was a huge increase observed in the demand for tobacco. Per capita, tobacco consumption was increased by 9.2 percent between 2001 to 2004 (Makhabah et al., 2017). At present, almost 63 percent of Indonesian men smoke and thirty-four percent smoking prevalence (Makhabah et al., 2017). Due to the exposure to the smoke of cigarettes, nonsmokers get addicted to passive smoke that is more dangerous and harmful to human being. The Indonesian government and the partner elite of the country are beneficiaries of the tobacco industries and the economic benefits are huge that restrict the government actions (Makhabah et al., 2017). Indonesian government managed a suitable condition for the multinational companies to set their plants of cigarette manufacturing. People are not restricted, even a huge population of children used to smoke regularly. The multinational companies are also posing pressure on the Indonesian government to ease the smoking rules for the public and manufacturers (Makhabah et al., 2017).

Currently, smoking is the basic problem that need to solve by the Indonesian nation, most of the population is addictive to the use of tobacco. Indonesia is ranked at number three in the whole world for the consumption of tobacco after China and India (Prabandari \& Dewi, 2016). The rapid increase in the smoking habit among the young generation is alarming in Indonesia as most of the cigarette companies focus on the young generation. World Health Organization calculated that 225,720 individuals are died every year in Indonesia because of smoking (Prabandari \& Dewi, 2016). The number of deaths due to the use of tobacco in Indonesia accounts for 14.7 percent of the total deaths (Prabandari \& Dewi, 2016). Smoking is not only harmful to young smokers, but it is also harmful to every age and the smoke of cigarettes affects children and adults.

According to the studies, it is revealed that tobacco consumption and spending cost 378.75 trillion rupiah to Indonesia during 2013 (Prabandari \& Dewi, 2016). The addictive nature of tobacco and other health issues are the primary points of concern for the authorities. Indonesia ranked third in smoking prevalence and it is estimated that more than $75 \%$ of the population is used to smoke regularly (Prabandari \& Dewi, 2016). Data shows that the smoking trend of beginners at the age of 10-18 increased at an alarming $9.1 \%$ in recent years (Prabandari \& Dewi, 2016). Cigarette industries are involved in the 
widespread prevalence of smoking in Indonesian society. It is accounted that more than 225,720 people died because of smoking and it is more than $14 \%$ of total deaths in the country (Prabandari \& Dewi, 2016). Smoking causes societal damage that altered the social health demography. The increased rate of morbidity and mortality alarmed the social and communal authorities to consider the effect of increased smoking trends in the country (Prabandari \& Dewi, 2016).

The Indonesian authorities are lean toward the cigarette industry because of the political and personal gain of elite class. Political class of Indonesia have their interest in cigarette industry that are of economic basis; poor legislation and lack of awareness campaigns are also part playing factors managed by political elite to hide the issues (Puig, 2017). Significant increase in hypertension and cancer cases in recent years are also evident; cancer cases are increased from $7 \%$ to $15 \%$ and hypertension cases are elevated from $17 \%$ to $54 \%$ (Puig, 2017). Diseases linked with smoking and poor air quality are increasing with time and most of the diseases are linked with intensive smoking habits of the people (Puig, 2017).

The economic gains from the tobacco industry are surpassed by the medical expenses in recent years that alarmed the government authorities to control tobacco consumption. There are many environmental consequences of cigarette consumption; the butts of cigarettes are decomposed in not less than 10 years (Puig, 2017). Indonesia has a huge cigarette industry manufacturing more than 5.5 trillion cigarettes per minute. The cigarettes are also exported across different countries and the multinational companies have their production hub in Indonesia. Indonesia is the only country in Asia that did not ratify the "Framework Convention on Tobacco Control" (FCTC). The loss of legislations to control the consumption of tobacco is based on the economic benefits of certain political elite groups (Puig, 2017). Indonesia should strengthen the road map of legislations and social control of tobacco consumption to help support their civilian population (Puig, 2017). The disease incidents in the country are elevated posing severe health risks to the youth. Smoking education should be given to all classes of society especially the middle and poor class of society (Puig, 2017).

Indonesia is the largest cigarette producing country in the world and it also produces tobacco. The increased death rate in youth because of smoking is the point of concern for the social activists. Social groups and activists 
always urge the government to support them by the laws that can control public smoking and limit the campaigning of the multinational companies in the social system (Rosser, 2015). In Indonesia, more than 600,000 premature deaths are accounted for because of smoking and there are also issues of youth age deaths because of tobacco consumption in which $72 \%$ are women (Rosser, 2015).

Indonesia produces more than 360,000 tons of tobacco that produces more than 360 billion sticks of cigarettes in 2014 (Rosser, 2015). The data shows that the cigarette industry is powerful in the country and it is directly linked with the economics of the country. The limitation of legislations and legal actions to control smoking consumption is limited to make the tobacco industry flourish (Rosser, 2015). It is estimated that tobacco control will not harm the farmers of tobacco crops, as Indonesia is the exporter of cigarettes and most of the multinational companies have plants that export their products across the globe (Rosser, 2015). Cigarette manufacturing facilities are also filled with children that are involved in the manufacturing process. The involvement of children's in cigarette manufacturing is one of the key factors impact the social behavior of children toward smoking. Most of the children get used to smoke because of easy access to cigarettes (Rosser, 2015).

\section{Tobacco Control: Role of Media}

Television combines the capabilities of radio, cinema, photography, painting, theatre. By synthesizing the image and sound, it can achieve almost complete resemblance to the transmitted pictures, to ensure the coincidence in time of events and spectator observation of them (Rosser, 2015). The following reasons stand out for such a rapid and massive spread of television: (1) Information is figurative, holistic in nature and therefore highly accessible; (2) Telecasts are easy to understand (do not even require basic literacy); (3) The effect of personal presence, participation; and (4) A significant part of the information a person receives through vision (this is the main channel for obtaining information about the world).

In order to identify what role mass media should play in disseminating health information, it is necessary to determine the purpose and functions of the media in Indonesian society(Rosser, 2015).American theorists and historians of the press identify four theories that characterize the media, each of which has its own specific goal 
(Rosser, 2015). Firstly, it is an authoritarian theory, the purpose of which is to maintain and implement the policies of the current government, as well as to serve the state. Secondly, libertarian theory. Its purpose is to inform, entertain and sell, but mainly to help find the truth and control the government. Thirdly, this is the theory of social responsibility, the purpose of which is to inform, entertain and sell, but basically to transfer the conflict to the level of discussion (Schröderset al., 2017). And the fourth theory is socialist. Its purpose is to contribute to the success and maintenance of the socialist system, the party dictatorship (Schröderset al., 2017).

Health acts as one of the necessary and most important conditions for an active, creative and fulfilling human life in society (Schröderset al., 2017). This is exactly what K. Marx paid attention to at one time, presenting the disease as life constrained in its freedom. Inadequate level of health has a negative impact on the social, labor and economic activity of people, on the productivity and intensity of their labor; adversely affects a number of indicators of the natural movement of the population, as well as the health and physical development of offspring (Schröderset al., 2017). In this regard, health information should occupy a leading place in the information space system of television, radio, the press and the Internet (Schröderset al., 2017).

This is particularly relevant against the background of a general deterioration in the health of Indonesians. Every year, medical statistics record an increase in the incidence rate and an increase in the number of people with disabilities, which in turn adversely affects the demographic situation (Sebayang, Dewi, Lailiyah\& Ahsan, 2019). The mortality rate in 2005 reached 16.1 $\mathrm{ppm}$. Of concern is the increase in mortality in young age cohorts (Sebayanget al., 2019). In 2005, life expectancy at birth in Indonesia was 65.3 years: for men - 58.9 years, for women -72.3 years. Such a significant difference (13.4 years) between the expected life expectancy of men and women is not found in any country in the world (Sebayanget al., 2019). This gap significantly exceeds the performance of most countries, where this value averages from 5 to 7 years (Sebayanget al., 2019).

To maintain health, the urgent task is to create a new health culture among the entire population, which not only reduces the likelihood of diseases but also allows you to gradually strengthen the vitality of a person using traditional and nontraditional methods of preventing and treating diseases (Sebayanget al., 2019). It is impossible to change people's 
attitudes to their health without the help of the most powerful tool for forming public opinion - the media. The role of the media in shaping the worldview, values, norms, ideals, and behaviors of both an individual and society is invaluable (Sebayang et al., 2019). Television, radio, and the press, performing educational, educational, informational, cultural and spiritual functions, can increase the interest of the population in the problems of maintaining a high level of their health (Sebayang et al., 2019).

Currently, the urgent research problem is the study of the media information field what kind of social color has disseminated health information. It should be noted that modern media can have both positive and negative effects of disseminating health information (Septiono \& Kunst, 2018). A positive role can be played by social advertising. Advertising of toothpastes, shampoos, hygiene products, etc. helps to strengthen the need for personal hygiene in the minds of people (Septiono \& Kunst, 2018). Advertising on hard liquor products is currently prohibited on television. It is obvious that such measures must also be taken in relation to tobacco addiction. In addition, to effectively combat bad habits, the prohibition of such advertising is required not only on television but also on radio and on- street billboards (Septiono \& Kunst, 2018). In general, it can be noted that in Indonesia there are not enough specialized publications and programs devoted to the formation of a value attitude to health. Modern publications and programs promote those patterns of behavior that do not contribute to improving health, but rather lead to a weakening of the body's viability (Septiono \& Kunst, 2018). A policy to regulate the activities of the media can and should protect the population from the harmful effects of materials related to violence, risky behavior, and substandard advertising (Septiono \& Kunst, 2018).

It must be remembered that the main role of the media in a democratic state is to provide positive information that will be in demand by the population. For the formation of value orientations and motivations to maintain and strengthen their own health, it is necessary that positive medical information is broadcast regularly, as well as considering the characteristics of the audience (interests, age, gender) (Tandilittin, 2016). The information on the possibilities and methods of maintaining health depends on how competently, professionally, and readily available the effectiveness of the media. The formation of a healthy lifestyle should be the focus of social 
health policy. Comprehensive health promotion and prevention programs should not be reduced to separate measures for organizing medical care, it is necessary that they include measures of hygienic education, to combat alcoholism, drug addiction, smoking, and other risk factors, activation of physical education, measures to create a healthy image life (Tandilittin, 2016).

\section{Tobacco Control: Global Perspective}

More and more countries have introduced various legislative measures to ensure that people do not start smoking, and those who have already become a victim of a bad habit - at last from her refused (Tandilitin, 2016). According to the World Health Organization, today anti-smoking laws work in countries where a total of about $63 \%$ of the world's population (4.7 billion people) live. The main control tool is raising excise taxes on cigarettes and banning or restricting tobacco advertising and marketing. In some countries, prohibitive measures prevail, in others, the focus is on prevention and education about the dangers of smoking (Van den Brand, Nagelhout, Hummel, Willemsen, McNeill \& Van Schayck, 2019). Some EU states, in their strategy, are still turning to more conservative methods. Thus, the ban on smoking in public places, restaurants, and pubs in most Western European countries was introduced more than ten years ago (Tandilittin, 2016). Fines for smoking in the wrong places reach several hundred euros.The Australian authorities went further and in 2012 introduced an anonymous design for cigarette packs with warnings about the dangers of smoking and unpleasant photographs of infected organs. Their example was followed by France, Great Britain, New Zealand, and other countries (Tandilittin, 2016).

In the United States, in addition to standard measures, smokers increased the cost of health insurance, thus making a bad habit very burdensome from a financial point of view. However, unfortunately, strict prohibitions do not always turn out to be effective - the level of smoking even in many developed countries decreases slowly and remains at a relatively high level. Therefore, a trend has recently been gaining momentum to reduce health risks by switching smokers from cigarettes to less harmful innovative products. Some states even include the use of such alternative products in their list of cigarette control tools. For example, electronic cigarettes and other smokeless nicotine delivery systems are already recognized by British experts as an effective way to 
refuse cigarettes (van den Brand et al., 2019).

In our country, an active antismoking campaign began about Five years ago, when the American Bloomberg Initiative Fund started issuing grants to Indonesian NGOs in the fight against smoking (van den Brand et al., 2019). The state joined in full force in 2013, when the law "On protecting the health of citizens from the effects of surrounding tobacco smoke and the consequences of tobacco consumption" was adopted (Christiani, Dugdale, Tavener \& Byles, 2017). He imposed a complete ban on smoking in all closed public places in accordance with the WHO Framework Convention on Tobacco Control. New comprehensive antismoking measures are bearing fruit, but Indonesians still smoke much more than in the United States and the EU. According to the Ministry of Health of the Indonesian Federation, in the first two years of the active antitobacco campaign, the number of smokers in our country decreased by about 5\% (Christiani et al., 2017).

The United Kingdom boasts one of the most successful anti-smoking strategies - in 2015 , less than $17 \%$ of the adult population smoked there, which is the smallest amount in the history of statistics (Christiani et al., 2017). For comparison, in Indonesia, the indicator of the same year was twice as high - 34\%. In addition, a new ambitious "Smoking Control Plan" for 2017-2022 has recently been introduced in the UK (Christiani et al., 2017). Since he is already showing good results, we will consider it in comparison with the Indonesian antitobacco concept, planned for the same time period (Christiani et al, 2017).Both Indonesia and the UK, in general, resort to similar generally recognized measures to combat tobacco smoking, however, on several issues, the approaches of countries vary significantly (Christiani et al., 2017).

Take tobacco control among young people, for example. In Indonesia, it is believed that electronic nicotine delivery systems can be very attractive for minors. Indonesian experts are particularly concerned that using vapes is not the first step to regular smoking (van den Brand et al., 2019). In this regard, the authors of the anti-tobacco concept call for a ban on the sale of such products to persons under the age of 18 (van den Brand $e t$ al., 2019). In the UK, the age limit for the sale of electronic cigarettes was introduced two years ago, and now they look at the problem much more widely. Studies say that children are beginning to become interested in cigarettes, first, the adopted behavior model of adult smokers. In a 2014 study, $82 \%$ of British smokers 
reported having smokers in their families (van den Brand et al., 2019). Therefore, the UK Ministry of Health seeks to aid adult smokers, realizing that this directly affects the number of minors who smoke (van den Brand et al., 2019).

When assessing the potential harm and possible benefits of electronic cigarettes, the British authorities refer to their own research, medical statistics, as well as to the results of various independent research institutes and centers (Veruswati, Asyary, Nadjib \& Achadi, 2018). In turn, our Ministry of Health adheres to an extremely conservative approach, bypassing existing scientific data, confining itself to general phrases and calls for additional study of this new category of products. But our anti-smoking concept is quite inventive in the sense of regulating traditional cigarettes. Several particularly exotic norms have already caused widespread discussion in the media and received mixed reviews from other departments and the expert community (Veruswati et al., 2018). For example, the document proposes to close access to tobacco products for all citizens born after 2015 and to increase the working hours for those workers who go on a smoke break during the working day (both measures, according to the Ministry of Justice, contrary to the norms of the Constitution, as well as civil and labour laws) (Veruswati et al., 2018). The concept also includes a ban on smoking in communal apartments, even if all owners have nothing against it, openly discriminating against room owners against owners of entire apartments (Veruswati et al., 2018).

In addition, the authors urge the restriction of tobacco companies in the implementation of their corporate social responsibility (CSR), believing, probably, that social activity at the expense of "vicious" business has no right to exist. Some also believe that the CSR of such companies is just a tool for earning PR points (Veruswati et al., 2018). However, given the severe bans on marketing and advertising in the tobacco industry, these restrictions raise questions - companies allocating money for social purposes cannot legally use this to promote their products (Veruswati et al., 2018).

The most important difference between the anti-tobacco campaigns of the two countries is in relation to innovative nicotine-containing products that can reduce the health risks of smokers. After all, alternatives to traditional cigarettes have long been not only vapes (Veruswati et al., 2018). The development has gone far ahead: innovation is mainly aimed at eliminating the burning of tobacco and thereby reduce the level of toxic substances entering the smoker's 
body. New products are gradually appearing all over the world and are no longer considered something rare and "overseas" (Veruswati et al., 2018). A few years ago, the production of electronic cigarettes was concentrated mainly in China, and not all of these products could be called quality (Veruswati et al., 2018). Today, the development, production, and study of such devices is carried out by large international companies that invest a lot in implementing the concept of harm reduction and put product quality at the forefront.

In view of the possible harm reduction from such products, it is not the best anti-smoking move to completely ban and deny innovation in the tobacco industry. To effectively regulate alternative products, it would be more reasonable to introduce not prohibitive, but control measures in the context of which electronic nicotine delivery systems would be considered as a separate category (Wipfli \& Samet, 2016). Specialists from the British Ministry of Health rely on research and statistics, according to which only in 2016 England 2 million consumers used electronic cigarettes, as a result of completely giving up smoking (Wipfli \& Samet, 2016). Moreover, 470 thousand people continued to use electronic cigarettes during attempts to quit smoking.
English experts admit that the best thing for a smoker is, of course, to completely stop smoking and consume nicotine in all forms, but they put the second place in the transition to less harmful electronic cigarettes (Wipfli \& Samet, 2016). In this regard, the agency notes the importance of "increasing the availability of safer alternatives to smoking." At the same time, however, the UK Department of Health aims to inform and disclose all information regarding research on electronic cigarettes, regardless of the results (Wipfli \& Samet, 2016). The Indonesian Ministry of Health, on the contrary, proposes to restrain their distribution, repeatedly noting that cigarettes, vapes, and other innovative products are equally harmful. It is only surprising that this statement is not supported by any real scientific justification (Wipfli \& Samet, 2016).

Despite the growing popularity of electronic cigarettes in the world, the anti-smoking concept of Indonesia does not provide for separate legislative regulation of these products (Wipfli \& Samet, 2016). Proponents of electronic nicotine delivery systems note that preparing the legal framework for these products is crucial for controlling the quality of devices, as well as for separating products from traditional cigarettes. It is fair to say that there is currently no separate regulation of these devices in 
any country, however, several states are actively considering the possibility of a corresponding change in their legislation (Wipfli \& Samet, 2016).

Indonesian parliamentarians also did not stand aside and have already submitted several bills that would equate electronic cigarettes with traditional tobacco products. The authors of the Indonesian antismoking concept, in turn, insist on the introduction of a special tax on the sale of ENDS in 2018, in addition, proposing to prohibit any official reporting that this product is less harmful, knowingly noting that such statements will be false. Legislative requirements in the UK dictate exactly the opposite: the restrictions adopted for conventional cigarettes do not apply to electronic cigarettes because experts consider vaping products to be of lower risk. The fact is that in electronic cigarettes and tobacco heating systems, the combustion process does not occur, while most of the harmful substances in tobacco smoke are combustion products (World Health Organization, 2017).

According to the UK Ministry of Health, steam from electronic nicotine delivery systems contains 95\% less harmful substances than cigarette smoke (World Health Organization, 2017).After a comparative analysis of the two concepts and in view of the successful experience of the United
Kingdom, the following is obvious; prohibitive measures in anti-tobacco legislation are not enough to achieve a significant reduction in the number of smokers (World Health Organization, 2017). This thesis is supported by leading Indonesian experts in the field of public health. "Doctors should strongly recommend stopping smoking for their patients. It is necessary to fight with smoking, but not with smokers. According to our data, every third smoker wants to quit smoking. We need to help them. There are different ways of anti-nicotine therapy. In England, in the first 5 years of the implementation of the antitobacco program, launched in 2011, the proportion of smokers decreased from 20 to 15\% (World Health Organization, 2017). There was a deliberate work of doctors and psychologists with smokers, including support for those who used alternative nicotine products to quit smoking. Today, about 2 million people use electronic cigarettes and have completely abandoned smoking (World Health Organization, 2017).

Strict prohibitions are advisable with competent preparation of the society: "There are experience in banning the sale of cigarettes to people born after a certain year in a number of countries." In Singapore, these measures require serious preparatory work, because you can create laws, the 
question is how it will be implemented (Yunus, Ariawan \& Nurwidya, 2019). "Vapes are a more sophisticated recruitment of the younger generation by creating a certain subculture that we are indifferent to today. Here, too, it is necessary to regulate, or simply put, to ban smoking of vapes." As an important element of public health policy, smoking control should include the most effective mechanisms and tools. This is obvious, as well as the fact that history has a lot of examples when ill-conceived and uncompromising prohibitions led to the opposite of the desired results (Yunus, Ariawan \& Nurwidya, 2019).

Undoubtedly, the expansion of the preventive base and the provision of real medical assistance to smokers can become significant elements of a program to reduce smoking in the country (Yunus, Ariawan \& Nurwidya, 2019). In addition, it is important to inform smokers who are addicted to nicotine and do not want to give up their habit that alternative products exist that can reduce the harm to their health - many smokers today simply do not know about such an opportunity. Despite all the prohibitions, few people manage to quit smoking overnight, and for those who are not able to do this here and now, we have so far only one alternative is available - "drop it or die". In this sense, the time-tested and proven methods from the English concept look much more humane, and most importantly, they really help to achieve the main goal in the fight against smoking - to save lives (Yunus, Ariawan \& Nurwidya, 2019).

\section{Tobacco Control; National Context}

The tobacco control program and its success is dependent on the cooperation of all of the involved parties including the regional and national government, and the nonprofit organizations and nongovernmental organizations (NGOs). Ministry of Health Informant has mentioned that the collaboration of the NGOs in tobacco control is a positive force for the sector (Zulfikar, 2017). Furthermore, the direct involvement of the Ministry of Health in the control program has also had a positive influence. Directorate of PTM and Promkes is also supporting the tobacco control program. Tobacco control programs and activities related to reducingits use are proved to be a joint between the central government and regional governments. Ministry of Health is further divided into directorates and divisions. Harmony among different divisions is a way of success to achieve the goals (Zulfikar, 2017).

The joint collaboration of the regional and central government in 
tobacco control is also playing a main role in tobacco control. According to the Ministry of Health, the success of the tobacco control program is due to the joint collaboration of NGOs, academics and local people (Zulfikar, 2017). It is considered to be a mutual success of all the regional and central parties involved in the program. Achievement of goals in a country where there are no restrictions is a hard job to do. Successful implementation of no-smoking policy for youth need hard steps that should be taken right now, NGO's are working for awareness and government should engage the public sector in a cooperative manner to gain the momentum (Zulfikar, 2017). Tobacco control activities can be implied through the help of regional and central government and such activities are limited to the development of awareness and no strict rules are defined for any agency of population set (Zulfikar, 2017).

A cross-sectoral collaboration is needed to apply the successful techniques to prevent the tobacco consumption."but it is related to various sectors, therefore, it is the most concerned about cigarettes, yes, the Health Service is supported by the relevant P3AP2KP Office that carries about child-friendly regional policies"(Respondent Sleman District Government). Children should be protected by the regional and central authorities to secure the future of the country; children and young people are the most impacting population groups that are not sufficiently aware of the danger posed by tobacco consumption (Herawati, Budiman, Haryono \& Mulyani, 2017). The conditions of collaboration and protection of children from smoking are important stepsfor the development of smoking free zones in public places to help protect people that are not smoking but inhaling the smoke produced all around. "There are nine areas that are free of cigarette smoke (Herawati et al., 2017). The city (the city government of Yogyakarta) has a Regional Regulation on KTR, there is no house listing. That is great, to the private homes, so that house cannot (smoking) must be outside "(Respondent of the Local Government of Bantul Regency) (Herawati et al., 2017).

Gunung Kidul Health Office playing a key role in the awareness campaigns across Indonesia to help people struggling with tobacco consumption (Herawati et al., 2017). There are also obstacles that prevent the use of preventive measures including the different approaches of federal and local governments to attain the success in tobacco control program. The priorities of regional and central governments also differ, the pressure of political elite and 
multinational groups related to tobacco industries on the central government restrict strong steps to counter tobacco consumption in the country (Herawati et al., 2017). Regional governments are more struggling to help people struggling with smoking, but the central government hasits own priorities that limit them to small initiatives like smoking free corners all across the busy city areas. The central government is working slowly but the steps are taken to counter the widespread epidemic of tobacco consumption that led to the serious issues of health (Herawati et al., 2017).

\section{Opportunities and Challenges}

Coordinator of the Indonesian National Program Institute for Social Development addressed the public that the current president of Indonesia is keen to make a comprehensive tobacco control policy for the future development of a healthy society. The step addressed by the coordinator shows the intention of state authorities to protect the vulnerable groups of the society that includes young students and women. Smoking is the key to deteriorating health conditions and an increased incidence of evitable diseases. The devised policy for tobacco control in 2013 that addresses the commitment of the government to reduce smoking up to $10 \%$ also fruit positive results in upcoming years (Yunus, Ariawan \& Nurwidya, 2019). Social education and awareness campaign to minimize the smoking issues in youth are the main focus of the NGO's and other socially activated institutes across the country (Yunus, Ariawan \& Nurwidya, 2019). By decreasing smoking habits, Indonesian people can save their lives from noncommunicable diseases.

There is a need for social activation of people and the social development of norms that restrict people. Tobacco control is not a simple movement in Indonesia, it is a complex movement that can never be succeeded without any help from authorities and legislating bodies (Yunus, Ariawan \& Nurwidya, 2019). Regional issues of tobacco consumption also relate to the norms of society that can be changed through campaigning and social awareness. At the national level, the marketing of tobacco-based products should be banned completely, and the government should impose taxes and duties to restrict the local sales of such products (Yunus, Ariawan \& Nurwidya, 2019). The government should bound the companies to mention the warning of health issues on cigarette backs to make sure every consumer will be made aware. The pictures on cigarette packs should be changed and enlarged with time to 
make public ware and risk factors (Yunus, Ariawan \& Nurwidya, 2019).

The development of social networks and policy statements to control cigarette consumption in the country can step forward. Coordination between regional and central government with the community also play its role to avoid the danger of smoking (Zulfikar, 2017). The government should start an awareness campaign for the youth to make them secure from the dangerous consequences of smoking. Smoking is not dangerous for the consumer, but the environment is also impacted by aggressive smoking. Indirect inhaling of smoke can cause serious issues; children working in the industry should be restricted to work in tobacco industries (Zulfikar, 2017). Major challenges faced by the government include economic consequences of restriction on tobacco industries, political and social influence of beneficiariesand lack of interest of government. The political elite is the major contributor to smoking policy in the society that follows their interest, but it has serious consequences for the common man (Zulfikar, 2017).

\section{CONCLUSION}

Tobacco causes serious health risks and it is the most damaging legal drug in the world except alcohol. The estimated deaths because of smoking are more than 5 million annually. Indonesia has poor legislative restrictions and the country has a huge industry of tobacco and related products. The economic benefits gained by the tobacco industries are the biggest concern for the political elite that favors tobacco industries in the country because of their economic benefits. Indonesia isthe largest manufacturer of cigarettes export most of its products across the globe, but more than $72 \%$ of Indonesian people are consuming tobacco regularly. Indonesian community and vulnerable groups largely comprise of children and women that have no idea what they are doing with their health. The government authorities are reluctant to adhere to the $\mathrm{WHO}$ devised rules to be implemented to control tobacco because of their economic and political benefits. Multinational companies also have stronghold of the industry that leads them to make corrupt all authorizing bodies in the country for the sake of their business. Social activists and social bodies are working progressively with the aid of regional authorities to control tobacco consumption. The legislation made in 2013 by the Indonesian government still not implemented which resulted in the increased rate of young cigarette consumers in the market. To help 
control the cigarette consumption, it is important to make a unified pathway for awareness and concrete steps to control cigarette consumption.

\section{REFERENCES}

Ariani, D. R., \& Mulyono, S. (2019) "Relationship Follows Trends and Smoker's Families with Perceptions of Smoking in Primary School Age Children in Karawang, Indonesia", KnE Life Sciences, pp. 185-193.

Ariani, D. R., Mulyono, S., \& Widyatuti. (2019) "Risk Factors for the Initiation of Smoking Behavior in Primary School Age Children in Karawang", Indonesia. Comprehensive child and adolescent nursing, 42 (sup1), pp. 154-165.

Assunta, M., \& Dorotheo, E. U. (2016) "SEATCA tobacco industry interference index: a tool for measuring implementation of WHO Framework Convention on Tobacco Control Article 5.3", Tobacco control, 25(3), pp. 313-318.

Astuti, P. A. S., Assunta, M., \& Freeman, B. (2018) 'Raising generation 'A': a case study of millennial tobacco company marketing in Indonesia", Tobacco control, 27(e1), e41-e49.

Berg, C. J., Fong, G. T., Thrasher, J. F., Cohen, J. E., Maziak, W., Lando, H., \& Salloum, R. G. (2018) “The impact and relevance of tobacco control research in low-and middle-income countries globally and to the US" Addictive behaviors, 87, pp. 162-168.

Christiani, Y., Dugdale, P., Tavener, M., \& Byles, J. E. (2017) "The Dynamic of Non-communicable Disease Control Policy in Indonesia", Australian Health Review, 41(2), pp. 207-213.

Cooper, J., Borland, R., McKee, S. A., Yong, H. H., \& Dugué, P. A. (2016) "Depression motivates quit attempts but predicts relapse: differential findings for gender from the International Tobacco Control Study", Addiction, 111(8), pp. 14381447.

Herawati, L., Budiman, J. A., Haryono, W., \& Mulyani, W. (2017) "Jayapura Teenagers Smoking Behavior", Journal of community bealth, 42(1), 78-82.

Lee, K., Eckhardt, J., \& Holden, C. (2016) "Tobacco industry globalization and global health governance: Towards an interdisciplinary research agenda", Palgrave communications, 2(1), 16037.

Makhabah, D., Ride, Y. O. S., Raharjo, F., Sutanto, Y. S., \& Suradi, S. (2017) "The Impact of Tobacco-Related Advertisement on Tenagers' Smoking Behaviour in Surakarta, Indonesia.

Prabandari, Y. S., \& Dewi, A. (2016) "How do Indonesian youth perceive cigarette advertising? A cross-sectional study among Indonesian high school students", Global health action, 9(1), 30914.

Puig, S. (2017) "Internationalization of Tobacco Tactics", Duke J. Comp. \& Int'l L., 28, 495.

Rosser, A. (2015) "Contesting TobaccoControl Policy in Indonesia", Critical Asian Studies, 47(1), 69-93.

Schröders, J., Wall, S., Hakimi, M., Dewi, F. S. T., Weinehall, L., Nichter, M., \& Ng, N. (2017) "How is Indonesia Coping with its Epidemic of Chronic Noncommunicable Diseases? A Systematic Review with Metaanalysis", PloS one, 12(6), e0179186.

Sebayang, S. K., Dewi, D. M. S. K., Lailiyah, S. U., \& Ahsan, A. (2019) "Mixedmethods Evaluation of a Ban on Tobacco Advertising and Promotion in Banyuwangi District, Indonesia", Tobacco control, 28(6), 651656. 
Septiono, W., Ng, N., \& Kunst, A. (2018) "The development of local smoke free policy of Indonesia in 2004-2015:, In Tobacco Induced Diseases (Vol. 16, No. 1, pp. 57-58). EUEP European Publishing.

Tandilittin, H. (2016) "What Should The Government Do To Stop Epidemic of Smoking Among Teenagers In Indonesia", Asian Cult Hist, 8(1), 140154.

van den Brand, F. A., Nagelhout, G. E., Hummel, K., Willemsen, M. C., McNeill, A., \& van Schayck, O. C. (2019) "Does free or lower cost smoking cessation medication stimulate quitting? Findings from the International Tobacco Control (ITC) Netherlands and UK surveys", Tobacco control, 28(Suppl 1), s61-s67.

Veruswati, M., Asyary, A., Nadjib, M., \& Achadi, A. (2018) "Current activities in smokes-free zone policy: a tobacco control care reviews in Indonesia”, Family Medicine \& Primary Care Review, (4), pp. 385-388.
Wipfli, H., \& Samet, J. M. (2016) “One hundred years in the making: the global tobacco epidemic", Annual review of public health, 37, pp. 149-166.

World Health Organization. (2017) WHO Report on the Global Tobacco Epidemic, 2017: Monitoring Tobacco Use and Prevention Policies. World Health Organization.

Yunus, F., Ariawan, W. P., \& Nurwidya, F. (2019) "Smoking Behaviors and Related Factor in Indonesian Patients with Chronic Obstructive Pulmonary Disease in National Reference Hospital for Respiratory Diseases", Pakistan Journal of Chest Medicine, 25(1), 06-10.

Zulfikar, A. (2017) Mapping the Indonesian Government's Position in the Decisionmaking Process of WHO FCTC Ratification. 